\title{
The Relationships Between Internet Addiction, Social Appearance Anxiety and Coping with Stress
}

\author{
Umay Bilge Baltacı ${ }^{1}$, Melike Yılmaz ${ }^{2} \&$ Zeliha Traş ${ }^{1}$ \\ ${ }^{1}$ Necmettin Erbakan University, Konya, Turkey \\ ${ }^{2}$ Ministry of Education, Konya, Turkey \\ Correspondence: Zeliha Traş, Education Faculty, Necmettin Erbakan University, Konya, Meram Yeniyol 42090, \\ Turkey. E-mail: zztras@gmail.com
}

Received: December 27, 2020

doi:10.5539/ies.v14n5p135

\author{
Accepted: February 18, 2021 \\ Online Published: April 26, 2021 \\ URL: https://doi.org/10.5539/ies.v14n5p135
}

\begin{abstract}
The purpose of this study is to examine internet addiction in terms of social appearance anxiety and strategies for coping with stress. The dependent variable of the research is internet addiction, and its independent variables are social appearance anxiety and strategies for coping with stress. The study group of the research consists of 481 undergraduate and postgraduate students as 318 women (66.1\%) and 163 men (33.9\%). In order to collect data in the study, Short Version of Young's Internet Addiction Test, The Social Appearance Anxiety Scale, The Stress Coping Strategy Scale, and Personal Information Form were used. Descriptive statistics, correlation and multiple regression analysis were used to analyze the data. A positive relationship was found between internet addiction and social appearance anxiety of university students. While there is a positive relationship between submissive approach and helpless approach, which are the subscale of coping strategies, and internet addiction of university students, there is a negative relationship between self-confident approach and optimistic approach. The results of the research revealed that the submissive approach and self-confident approach, which are the subscale in for coping with stress, social appearance anxiety are predictive of internet addiction.
\end{abstract}

Keywords: internet addiction, social appearance anxiety, strategies for coping with stress, university students

\section{Introduction}

It is seen that the Internet, reaching more users day by day, is reshaping and developing many aspects of people's lives by integrating into daily life (Mihajlov \& Vejmelka, 2017). For example, the Internet affects many areas of life, from performing basic tasks such as shopping or paying bills to using social media to connect (Ryan, \& Lewis, 2017). The Internet may provide benefits and convenience to users, but excessive use can lead to some serious harm and/or psychological disturbances (Li \& al., 2020). The increasing use of the Internet has caused internet addiction to become a problem for some users (Chebbi, Koong, Liu, \& Rottman, 2020).

Internet addiction is defined as continuing to use the Internet despite having problems in social life, business life and daily work, and being constantly busy with the Internet (Young, 2007). According to Şahin and Korkmaz (2011), internet addiction is a concept that has become a harmful behavior caused by the lack of control mechanisms for individuals' internet use. It has been revealed that when the Internet is misused, it affects individuals' lives negatively and also has the potential to develop addiction (Young, 2004). In internet addiction, some of the reasons for individuals turning to the Internet can be listed as social anxiety, depressed mood, unhappiness, lack of self-confidence, desire to be alone, desire to spend time on the Internet, and being happy while using the Internet (Azher et al., 2014). Decrease in individuals' vocational and academic success, considering a life without the Internet as boring or not being able to think the life without the Internet is among the symptoms of internet addiction (Gökçearslan \& Günbatar, 2012). In addition, emotional-state disorder, adjustment disorder and perception disorder, which are seen in substance addicts, are also seen in internet addicts. There is also a feeling of tolerance and abstinence (Griffiths, 2005). The need for socialization, which is thought to be related to internet addiction, causes excessive internet use in individuals (Günüç \& Kayri, 2010). In this respect, it is remarkable that internet addiction is defined in an interpersonal and social framework (Rodgers, Melioli, Laconi, Bui, \& Chabrol, 2013). With the widespread use of the Internet, giving more importance to virtual life, people started to share photos and videos on the Internet. It was inevitable that this situation would affect the society. This is because social media plays a big role in creating the ideal body image of individuals (Silva, Taquette, \& 
Coutinho, 2014). The Internet and social media also provide many grounds for social comparison. Images presented on the Internet are often images of other users and can therefore be considered as suitable targets for appearance comparison (Rodgers, 2016). In this regard, it is considered that internet addiction is related to the perception of individuals about their appearance and the use of the Internet.

Social appearance anxiety, which is an important concept related to the person's perception about appearance, has been defined as an anxiety type in which individuals approach their bodies more comprehensively, and do not like their bodies physically (Hart et al., 2008). According to Leary and Kowalski (1995), social appearance anxiety is defined as the anxiety caused by the idea that people cannot create a positive impression on other people. Social appearance anxiety arises as a result of the negative perception of individuals about their body and appearance (Doğan, 2010). If a person feels a lack of creating positive impression on other people with whom $\mathrm{s} /$ he interacts, social appearance anxiety arises (Mülazımoğlu Ball1, Erturan İlker, \& Arslan, 2014). It is thought that individuals who do not like their physical appearance are introverted, pessimistic, insecure, inadequate in social situations, and have a personality trait that awaits constant approval from their environment (Çınar \& Keskin, 2015). Individuals who feel anxious about social appearance constantly try to hide their physical areas they do not like and seek communication opportunities through which they can be accepted in the society (Doğan, 2009). Social appearance anxiety can negatively affect individuals socially, academically and professionally (Dindar \& Akbulut, 2015). Again, individuals who experience this anxiety keep their distance and avoid from others in their close relationships (Alden \& Taylor, 2004). In addition, when individuals encounter a situation that threatens their body image, they will develop and use a variety of coping strategies to adapt or face these stressful thoughts, feelings and situations (Soponaru, Bojian, \& Iorga, 2016). In this respect, one of the concepts related to social appearance anxiety can be considered as stress and coping with it (Reilly, \& Rudd, 2007; Jain, 2016).

Stress arises as the cause of the mutual interaction between the individual and the environment. However, the occurrence of stress is related to the meaning that the individual gives to the event or situation (Lazarus and Folkman, 1984). Coping with stress is a necessary condition for maintaining a productive life by protecting physical and mental health (Baltaş \& Baltaş, 1998). Managing the impact of stress depends on the person's perception about an event or a situation and the coping strategy (Şahin, 1994). Coping with stress is divided into two as problem-focused coping style and emotion-focused coping style (Lazarus \& Folkman, 1984). Problem-focused coping is aimed at resolving the stress-causing situation in a constructive way, and emotion-focused coping is for regulating the emotion that occurs when the stressful situation emerges (Folkman, 2010). People can use various coping styles together in the face of stress (Thoits, 1995). Individuals, who are successful in dealing with stress, have skills such as creating an alternative plan, making an accurate assessment, and anticipating the long-term effects of coping responses (Antonovsky, 1979). However, individuals, who fail to cope with stress, show a withdrawal in the face of difficulties they face and do not strive for a solution. Often they become aggressive, depressed, nervous or passive and blame themselves or others (Kleinke, 2007). In addition, stress has various effects on the individual. For example, it is effective in such concepts as stress sleep disorders (Kalmbach, Anderson, \& Drake, 2018), eating disorders (Naish, Laliberte, MacKillop, \& Balodis, 2019), burnout (Fares, Tabosh, Saadeddin, Mouhayyar, \& Aridi, 2016), and fear of extinction (Maren \& Holmes, 2016). It is also observed that stressful life events increase the addictive use of the Internet (Li et al., 2016).

In line with the relevant literature, the aim of this study is to examine the relationships between university students' internet addiction, social appearance anxiety, and strategies for coping with stress. In addition, the predictive effect of social appearance anxiety and coping strategies on internet addiction was investigated.

\section{Method}

\subsection{Research Method}

This research was carried out by survey method to explain the predictive effect of social appearance anxiety and strategies for coping with stress on internet addiction. The survey method is a model based on a specific data collection process and analysis techniques (De Vaus, 2002). The dependent variable of the research is internet addiction, and independent variables are social appearance anxiety and strategies for coping with stress.

\subsection{Participant Characteristics}

The study group consisted of 481 undergraduate and postgraduate students, as $318(66.1 \%)$ women and 163 (33.9\%) men who voluntarily participated in the study. Grade level of the participants were: 1 person from preparatory class $(.2 \%), 76$ people from the 1 st grade $(15.8 \%), 63$ people in the 2 nd grade $(13.1 \%), 133$ people from the 3 rd grade $(27.7 \%), 159$ people from the 4 th grade $(\% 33.1), 15$ people from the 5 th grade $(3.1 \%), 4$ people from the 6 th grade $(.8 \%)$, and 30 postgraduates $(6.2 \%)$. 


\subsection{Data Collection}

The data were collected in the fall semester of the 2019-2020 academic years. The data collection tools were transferred to the Internet by adding necessary explanations. The data were collected from volunteer participants via Google Forms. It was explained to the participants that volunteering is essential and that they can stop working at any time. An e-mail address is given to participants who want detailed information. It took the participants 25-30 minutes to fill in the scales.

\subsection{Measuring Tools}

In the study, The Short Version of Young's Internet Addiction Test was used to measure participants' internet addiction; The Social Appearance Anxiety Scale was used to measure social appearance anxieties; The Stress Coping Strategy Scale was used to determine their strategies for coping with stress, and personal information form was used to obtain information such as gender and class.

The Short Version of Young's Internet Addiction Test: The scale was developed by Young (1998). The short form of the scale was created by Pawlikowski, Altstötter-Gleich, and Brand (2013). The scale consists of one dimension and 12 items. The scale was adapted to Turkish culture by Kutlu, Savc1, Demir, and Aysan (2016). Considering the results of Confirmatory Factor Analysis conducted, the fit index values were $\chi 2=144.93$, sd $=52$, RMSEA $=.072$, $\mathrm{RMR}=.70, \mathrm{GFI}=.93, \mathrm{AGFI}=.90, \mathrm{CFI}=.95$ and $\mathrm{IFI}=.91$. Reliability coefficient was found as .91 (Kutlu, Savc1, Demir \& Aysan, 2013). When the obtained results are examined, it is seen that the scale is the suitable measurement tool in terms of validity and reliability. The reliability coefficient of the scale in this study was found as .84 .

The Social Appearance Anxiety Scale: The Social Appearance Anxiety Scale was developed by Hart et al. (2008) and adapted to Turkish culture by Doğan (2010). It is a one-dimensional, 5-point Likert type scale with 16 items. According to Exploratory Factor Analysis results, $53.4 \%$ of the total variance was explained. As a result of the Confirmatory Factor Analysis, it was found that RMSEA $=.051, \mathrm{NFI}=.98, \mathrm{CFI}=.99$, IFI $=.99$, RFI $=.98$, GFI $=.93$ and $\mathrm{AGFI}=.90$. The factor loads of the Social Appearance Anxiety Scale vary between .87 and .35 . Values show that the model fits well. The reliability coefficient of the scale was found to be $\alpha=.88$ (Doğan, 2010). In this study, it was found that $\alpha=.93$.

The Stress Coping Strategy Scale: The Stress Coping Strategy Scale was created based on The Ways of Coping Questionnaire of Folkman and Lazarus (1984). Adaptation of it to Turkish culture was done by Şahin and Durak (1995). The scale consists of 5 sub-dimensions: self-confident approach, optimistic approach, submissive approach, helpless approach, and seeking of social support. The reliability coefficients of the scale are $\alpha=.62-.80$ for self-confident approach, $\alpha=.49-.68$ for optimistic approach, $\alpha=.47-.72$ for submissive approach, $\alpha=.64-.73$ for helpless approach, and $\alpha=.45-.47$ for seeking ofsocial support (Şahin \& Durak, 1995). As a result of DFA performed by Doğan Laçin and Yalçın (2019), values, $2 / \mathrm{sd}=4.63$, RMSEA $=.081, \mathrm{NNFI}=.91, \mathrm{CFI}=.92$, SRMR $=.07$, were acceptable. In this study, the reliability coefficients are $\alpha=.84$ for self-confident approach, $\alpha=.74$ for optimistic approach, $\alpha=.46$ for submissive approach, $\alpha=.72$ for helpless approach, and $\alpha=.49$ for seeking of social support.

Personal Information Form: It was prepared by the researchers to get information about the participants' gender, age and grade level.

\subsection{Data Analysis}

The data were analyzed using SPSS Packet Program. While analyzing the data, descriptive statistics, correlation and regression analysis technique were used.

Table 1. Skewness and kurtosis values of variables

\begin{tabular}{lcc}
\hline & Skewness & Kurtosis \\
\hline Short Version of Young's Internet Addiction Test & .743 & .692 \\
Social Appearance Anxiety Scale & 1.043 & .476 \\
Self-Confident Approach Subscale & -.069 & -.584 \\
Optimistic Approach Subscale & -.054 & -.259 \\
Submissive Approach Subscale & .252 & .309 \\
Helpless Approach Subscale & .125 & -.187 \\
Seeking of Social Support Subscale & -.451 & .524 \\
\hline
\end{tabular}


Mahalanobis Distance, Cook's Distance, and Leverage values are used to determine outliers (Kannan \& Manoj, 2015). In the research, 15 data that were found to be outliers were excluded from the data set by looking at Mahalanobis Distance, Cook's Distance, and Leverage values. After the outliers were extracted, skewness and kurtosis values were examined to determine whether the data are suitable for normal distribution. That the skewness and kurtosis values of the variables are between +1.96 and -1.96 indicates that there is a normal distribution (Ghasemi \& Zahediasl, 2012). As can be seen in Table 1, kurtosis and skewness coefficients for Short Version of Young's Internet Addiction Test, The Social Appearance Anxiety Scale, and The Stress Coping Strategy Sub-scales are between -1.96 and +1.96 . By looking at the related values, it can be said that the data set shows normal distribution.

\section{Results}

Table 2. Correlations related to variables

\begin{tabular}{|c|c|c|c|c|c|c|c|}
\hline & 1 & 2 & 3 & 4 & 5 & 6 & 7 \\
\hline Internet Addiction (1) & - & $.452 * *$ & $-.285^{* *}$ & $-.220 * *$ & $.222 * *$ & $.342 * *$ & .003 \\
\hline Social Appearance Anxiety (2) & & - & $-.351 * *$ & $-.329 * *$ & $.200 * *$ & $.491^{* *}$ & -.063 \\
\hline Self-Confident Approach (3) & & & - & $.643 * *$ & $-.100 * *$ & $-.352 * *$ & -.013 \\
\hline Optimistic Approach (4) & & & & - & .082 & $-.358 * *$ & -.004 \\
\hline Submissive Approach (5) & & & & & - & $.368^{* *}$ & -.013 \\
\hline Helpless Approach (6) & & & & & & - & .051 \\
\hline Seeking of Social Support (7) & & & & & & & - \\
\hline
\end{tabular}

$* * \mathrm{P}<.01$

When Table 2 is examined, it is seen that there is a significant positive correlation between Short Version of Young's Internet Addiction Test scores and the score of The Social Appearance Anxiety Scale $(r=.45, p<.01)$ and Submissive Approach Sub-scale $(\mathrm{r}=.22, \mathrm{p}<.01)$ and Helpless Approach Sub-scale $(\mathrm{r}=.34, \mathrm{p}<.01)$. In addition, there is a negative relationship between The Short Version of Internet Addiction Test scores and the score of Self-Confident Approach Sub-scale $(r=-.28, \mathrm{p}<.01)$ and the Optimistic Approach Sub-scale $(r=-.22, \mathrm{p}<.01)$. No significant relationship was found between the score of Short Version of the Internet Addiction Test and the Seeking of Social Support Sub-scale.

Table 3. Regression analysis results regarding internet addiction variable

\begin{tabular}{|c|c|c|c|c|c|c|c|}
\hline Variable & B & SE & $\beta$ & $t$ & $p$ & Tolerance & $V I F$ \\
\hline Coefficient & 18.671 & 2.013 & & 9.275 & .000 & & \\
\hline Social Appearance Anxiety & .201 & .028 & .343 & 7.275 & $.000^{* * *}$ & .717 & 1.395 \\
\hline Self-Confident Approach & -.234 & .108 & -.117 & -2.168 & $.031 *$ & .549 & 1.821 \\
\hline Optimistic Approach & -.026 & .145 & -.010 & -.182 & .856 & .518 & 1.931 \\
\hline Submissive Approach & .324 & .132 & .110 & 2.462 & $.014 *$ & .793 & 1.261 \\
\hline Helpless Approach & .159 & .091 & .088 & 1.739 & .083 & .617 & 1.622 \\
\hline
\end{tabular}

The postulations required for the analysis were checked before proceeding to regression analysis. One of the postulations is that the Durbin-Watson (DW) coefficient takes a value between 1 and 3 as an indication that there is no auto-correlation (Field, 2018). The Durbin-Watson coefficient of this study was found to be as 1.763 . Another postulation is that the tolerance value is greater than .10, and the VIF value is less than 5 to avoid multicollinearity problems between variables (Daoud, 2017). The Tolerance (.717-.518) and VIF (1.931-1.395) values of this research are in the desired range. In this case, the data can be considered to comply with the conditions required for regression.

When Table 3 is examined, it is seen that Internet Addiction variable is predicted significantly $\left(\mathrm{R}=.50, \mathrm{R}^{2}=.25\right.$, $\left.\Delta \mathrm{R}^{2}=.24, \mathrm{~F}_{(5-475)}=30.838, \mathrm{p}<.001\right)$. The most powerful predictor variable is the Social Appearance Anxiety Scale $(\beta=.343, \mathrm{t}=7.275, \mathrm{p}<.001)$, and this is followed by Self-Confident Approach Sub-scale $(\beta=-.117, \mathrm{t}=$ $-2.168, \mathrm{p}<.05)$ and Submissive Approach Sub-scale $(\beta=.110, \mathrm{t}=2.462, \mathrm{p}<.05)$. Optimistic Approach Sub-scale and Helpless Approach Sub-scale do not significantly predict. Independent variables together explain 
approximately $25 \%$ of the total variance related to Internet Addiction.

\section{Discussion}

When the research findings are analyzed, a positive and significant relationship was found between internet addiction and social appearance anxiety of university students. In addition, it is seen that social appearance anxiety significantly predicts internet addiction. When individuals go on the Internet, they are exposed to a large number of images. It is thought that there are some evidence suggesting that exposure to idealized images depicted in the media is associated with negative emotions about the body and the individual's desire to change her/his weight and body shape (Monro \& Huon, 2005). Similar studies have also found a significant positive relationship between internet addiction, social media addiction and social appearance anxiety (Dikmen, 2019; Altındiş et al., 2017; Gilik, 2016). Similarly, in the study conducted by Doğan and Çolak, (2016), a significant positive relationship was found between social media use and social appearance anxiety. In addition, studies have found that there is a significant negative relationship between social appearance satisfaction and problematic internet use (Koronczai \& et al., 2013; Korkmaz, 2017; Ayar, Özalp-Gercer, Özdemir, \& Bektaş, 2018; Tras, Öztemel, \& Baltaci, 2019). Another study found a positive relationship between internet addiction and body image avoidance (Rodgers, Melioli, Laconi, Bui, \& Chabrol, 2013). Social appearance anxiety is one of the concepts that affect and relate to social anxiety (Levinson et al., 2013). Weinstein, Dorani, Elhadif, Bukovza, and Yarmulnik (2015) found that there is a significant relationship between internet addiction and social anxiety in young adults. When the literature is examined, there are studies revealing that there is a significant positive relationship between internet addiction and social anxiety, which is similar to the results of this study (Dong et al., 2019; Lee \& Stapinski, 2012).

Considering another finding of the research, a positive and significant relationship was found between internet addiction of university students and submissive approach and helpless approach, which are the subscale of strategies for coping with stress. In addition, according to the findings, it was observed that the submissive approach, which is a sub-dimension of strategies for coping with stress, significantly predicted internet addiction. Submissive approach and helpless approach are thought to be ineffective and emotion-oriented ways (Şahin \& Durak, 1995). A similar study found a significant positive relationship between internet addiction and emotion-focused coping styles (Zhou, Li, Li, Wang, \& Zhao, 2017). In another study, it was stated that people with high levels of internet addiction further use negative coping strategies (Chen, Quan, Lu, Fei, \& Li, 2015). In addition, studies have been found suggesting that there is a significant positive relationship between internet addiction and negative coping styles, and that negative coping styles are significant predictors of internet addiction ( $\mathrm{Li}$ et al., 2016). Addiction is generally considered to be the result of poor or inadequate coping mechanisms. Addicts who cannot cope with life stresses seem to turn to addiction for escape or comfort (DiClemente, 2018). Considering the relevant literature, the fact that individuals have dysfunctional coping styles, such as submissive approach and helpless approach when dealing with stress, may pose a risk factor for the addictive use of the Internet as an escape.

A negative and significant relationship was found between internet addiction of university students and self-confident approach and optimistic approach, which are the subscale of strategies for coping with stress. In addition, according to the findings, it was observed that self-confident approach, which is a sub-dimension of coping with stress, significantly predicted internet addiction. Self-confident approach and optimistic approach are considered as effective ways for the problem (Şahin \& Durak, 1995). A similar study found a significant negative relationship between internet addiction and problem-focused coping styles (Zhou, $\mathrm{Li}, \mathrm{Li}$, Wang, \& Zhao, 2017). In the study conducted by Chou et al. (2015), active coping styles of internet addicts were found to be significantly lower than individuals who do not have internet addiction. Li et al. (2016) found a significant negative relationship between internet addiction and positive coping. Also, coping positively is a significant predictor of internet addiction. Young (2004) stated that people with internet addiction take refuge in the Internet as a psychological escape method in order to overcome the stress they face. When using active coping styles, it can be considered that the focus will be on solving the problem rather than looking for an escape from the problem ( $\mathrm{Li}, 2008)$. When the relevant literature is considered, the findings of the research are compatible with it.

In this study, no significant relationship was found between internet addiction and seeking ofsocial support, which is a sub-dimension of coping with stress. In similar studies, no significant relationship was found between internet addiction and coping with stress by seeking social support (Ko \& Cho, 2006; Y1lmaz, 2016; Chwaszcz, Lelonek-Kuleta, Wiechetek, Niewiadomska, \& Palacz-Chrisidis, 2018). In the study conducted by Chou et al. (2015), no significant difference was found between individuals with and without internet addiction in terms of seeking help with emotional and instrumental reasons. The Internet may have a distracting feature for problems, and individuals may think that they can find online resources, including friends who help them cope with these problems (Netzley, 2014). Internet addicted individuals may have perceptions that they can find social support 
resources on the Internet.

\section{Limitations}

The findings of the research are limited to the ones obtained from the measurement tools. The study group of this research is limited to university students.

\section{Recommendations}

In this study, a significant negative relationship was found between social appearance anxiety and internet addiction. In addition, social appearance anxiety is a significant predictor of internet addiction. In future researches, the relationship between concepts such as social media addiction, which is a sub-type of internet addiction, and social appearance anxiety can be examined.

In this study, there is a significant negative relationship between internet addiction and self-confident and optimistic approach, which are active coping styles. Psycho-educational studies can be conducted to deal with stress positively and actively in individual or group psychological counseling services aimed at preventing and reducing internet addiction.

In this study, the relationship between internet addiction and stress coping styles was examined. Coping styles includes various ways, such as managing emotions, thinking constructively, regulating and directing behavior, controlling autonomous arousal, and seeking a solution in one's social circle in order to change or reduce stress sources (Gonzales, Tein, Sandler, \& Friedman, 2001). In future researches, other concepts related to coping with stress and internet addiction can be examined.

\section{Acknowledgments}

Identify grants or other financial support (and the source, if appropriate) for your study; do not precede grant numbers by No. or \#. Next, acknowledge colleagues who assisted in conducting the study or critiquing the manuscript. Do not acknowledge the persons routinely involved in the review and acceptance of manuscripts peer reviewers or editors, associate editors, and consulting editors of the journal in which the article is to appear. In this paragraph, also explain any special agreements concerning authorship, such as if authors contributed equally to the study. End this paragraph with thanks for personal assistance, such as in manuscript preparation.

\section{References}

Alden, L. E., \& Taylor, C. T. (2004). Interpersonal Processes in Social Phobia. Clinical Psychology Review, 24(7), 857-882. https://doi.org/10.1016/j.cpr.2004.07.006

Altındiş, A., Altındiş, S., Aslan, F. G., Aşici, N., İnci, M. B., Ekerbiçer H. Ç., \& Tokaç, M. (2017). Sosyal Medya Ağları ve Sosyal Görünüm Anksiyetesi. International Journal of Social Science, 64, 227-235. https://doi.org/10.9761/JASSS7353

Antonovsky, A. (1979). Health, Stress and Coping. San Francisco: Jossey-Bass.

Ayar, D., Özalp-Gerçeker, G., Özdemir E. Z., \& Bektaş, M. (2018). The Effect of Problematic Internet Use, Social Appearance Anxiety, and Social Media Use on Nursing Students' Nomophobia Levels. CIN Computers Informatics Nursing, 36(12). https://doi.org/10.1097/CIN.0000000000000458

Azher, M., Khan, R. B., Salim, M., Bilal, M., Hussain, A., \& Haseeb, M. (2014). The Relationship Between Internet Addiction and Anxiety Among Students of University of Sargodha. International Journal of Humanities and Social Science, 4(1), 288-293.

Balcı, Ş., \& Gülnar, B. (2009). Üniversite Öğrencileri Arasında İnternet Bağımlılığı ve İnternet Bağımlılarının Profili. Selçuk Illetişim, 6(1).

Baltaş, Z., \& Baltaş, A. (1988). Stresle Başaçıkma Yolları. İstanbul: Remzi Kitabevi.

Chebbi, P., Koong, K. S., Liu, L., \& Rottman, R. (2020). Some observations on internet addiction disorder research. Journal of Information Systems Education, 11(3), 3.

Chen, Q., Quan, X., Lu, H., Fei, P., \& Li, M. (2015). Comparison of the Personality and Other Psychological Factors of Students with Internet Addiction Who do and do not Have Associated Social Dysfunction. Shanghai Archives of Psychiatry, 27(1), 36-41.

Chou, W. P., Ko, C. H., Kaufman, E. A., Crowell, S. E., Hsiao, R. C., Wang, P. W., ... \& Yen, C. F. (2015). Association of stress coping strategies with Internet addiction in college students: The moderating effect of depression. Comprehensive Psychiatry, 62, 27-33. https://doi.org/10.1016/j.comppsych.2015.06.004

Chwaszcz, J., Lelonek-Kuleta, B., Wiechetek, M., Niewiadomska, I., \& Palacz-Chrisidis, A. (2018). Personality 
traits, strategies for coping with stress and the level of internet addiction-A study of polish secondary-school students. International journal of environmental research and public health, 15(5), 987. https://doi.org/10.3390/ijerph15050987

Çınar, H., \& Keskin, N. (2015). Öğrencilerin Sosyal Görünüş Kaygısının Öğrenim Yeri Tercihlerine Etkisi. Electronic Journal of Vocational Colleges, 457-465.

Daoud, J. I. (2017, December). Multicollinearity and regression analysis. In Journal of Physics: Conference Series (Vol. 949, No. 1, p. 012009). IOP Publishing. https://doi.org/10.1088/1742-6596/949/1/012009

De Vaus, D. A. (2002). Surveys in social research. Allen \& Unwin. https://doi.org/10.4135/9781446263495

DiClemente, C. C. (2018). Addiction and change: How addictions develop and addicted people recover. Guilford Publications.

Dikmen, O. (2019). Genç Erişkinlerde İnternet Bağımlılı̆̆ Düzeyleri ile Sosyal Görünüş Kaygısı ve Yalnızlık Düzeyleri Arasındaki İlişkinin İncelenmesi. Yüksek Lisans Tezi, Üsküdar Üniversitesi, Sosyal Bilimler Enstitüsü, İstanbul.

Dindar, M., \& Akbulut, Y. (2015). Role of Self-Efficacy and Social Appearance Anxiety on Gaming Motivations of MMOFPS Players. Computers and Education, 81, 26-34. https://doi.org/10.1016/j.compedu.2014.09.007

Doğan Laçin, B. G., \& Yalçın, İ. (2019). Üniversite Öğrencilerinde Öz-yeterlilik ve Stresle Başa Çıkma Stratejilerinin Bilişsel Esnekliği Yordama Düzeyleri. Hacettepe Üniversitesi Eğitim Fakültesi Dergisi, 34(2), 358-371. https://doi.org/10.16986/HUJE.2018037424

Doğan, T. (2009). Bilişsel ve Kendini Değerlendirme Süreçlerinin Sosyal Anksiyete Açısından İncelenmesi. Doktora Tezi, Sakarya Üniversitesi, Sosyal Bilimler Enstitüsü, Sakarya.

Doğan, T. (2010). Sosyal Görünüş Kaygısı Ölçeği’ nin (SGKÖ) Türkçe Uyarlaması: Geçerlik ve Güvenirlik Çalışması. Hacettepe Üniversitesi Eğitim Fakültesi Dergisi, 39, 151-159.

Doğan, U., \& Çolak, T. S. (2016). Self-concealment, social network sites usage, social appearance anxiety, loneliness of high school students: A model testing. Journal of Education and Training Studies, 4(6), 176-183. https://doi.org/10.11114/jets.v4i6.1420

Dong, B., Zhao, F., Wu, X. S., Wang, W. J., Li, Y. F., Zhang, Z. H., \& Sun, Y. H. (2019). Social anxiety may modify the relationship between internet addiction and its determining factors in Chinese adolescents. International Journal of Mental Health and Addiction, 17(6), 1508-1520. https://doi.org/10.1007/s11469-018-9912-x

Fares, J., Al Tabosh, H., Saadeddin, Z., El Mouhayyar, C., \& Aridi, H. (2016). Stress, burnout and coping strategies in preclinical medical students. North American Journal of Medical Sciences, 8(2), 75. https://doi.org/10.4103/1947-2714.177299

Field, A. (2018). Discovering statistics using IBM SPSS statistics. Sage.

Folkman, S. (2010). Stress, Coping and Hope. Psycho-Oncology, 19, 901-909. https://doi.org/10.1002/pon.1836

Ghasemi, A., \& Zahediasl, S. (2012). Normality Tests for Statistical Analysis: A Guide for Non-Statisticians. International Journal of Endocrinology and Metabolism, 10(2), 486. https://doi.org/10.5812/ijem.3505

Gilik, M. (2016). Ergenlerde İnternet Bağımlıllğının Sosyal Görünüş Kaygısı ve Çeşitli Değişskenlerle İlişkisinin İncelenmesi (İstanbul Yenibosna Çok Programlı Anadolu Lisesi Örneği). Yüksek Lisans Tezi, Nişantaşı Üniversitesi, Sosyal Bilimler Enstitüsü, İstanbul.

Gökçearslan, Ş., \& Günbatar, M. S. (2012). Ortaöğretim Öğrencilerinde İnternet Bağımlılı̆̆ı. Eğitim Teknolojisi Kuram ve Uygulama, 2(2), 10-24.

Gonzales, N. A., Tein, J. Y., Sandler, I. N., \& Friedman, R. J. (2001). On the limits of coping: Interaction between stress and coping for inner-city adolescents. Journal of Adolescent Research, 16(4), 372-395. https://doi.org/10.1177/0743558401164005

Griffiths, M. D. (2005). A Components Model of Addiction within a Biopsychosocial Framework. Journal of Substance Use, 10(4), 191-197. https://doi.org/10.1080/14659890500114359

Günüç, S., \& Doğan A. (2013). The Relationship Between Turkish Adolescent's Internet Addiction, Their Perceived Social Support and Family Activities. Computers in Human Behavior, 29, 2197-2207. https://doi.org/10.1016/j.chb.2013.04.011 
Günüç, S., \& Kayri, M. (2010). Türkiye'de İnternet Bağımlılık Profili ve İnternet Bağımlılık Ölçeğinin Geliştirilmesi: Geçerlik-Güvenirlik Çalışması. Hacettepe Üniversitesi Eğitim Fakültesi Dergisi, 39, 220-232.

Hart, T. A., Flora, D. B., Palyo, S. A., Fresco, D. M., Holle, C., \& Heimberg, R. G. (2008). Development and Examination of The Social Appearance Anxiety Scale. Assessment, 15(1), 48-59. https://doi.org/10.1177/1073191107306673

Jain, P. (2016). Perceived Stress, Optimism and Social Appearance Anxiety in Patients with Skin Diseases: A Comparative Study. IRA-International Journal of Management \& Social Sciences, 3(1), 50-62. https://doi.org/10.21013/jmss.v3.n1.p4

Kalmbach, D. A., Anderson, J. R., \& Drake, C. L. (2018). The impact of stress on sleep: Pathogenic sleep reactivity as a vulnerability to insomnia and circadian disorders. Journal of sleep research, 27(6), e12710. https://doi.org/10.1111/jsr.12710

Kannan, K. S., \& Manoj, K. (2015). Outlier Detection in Multivariate Data. Applied Mathematical Sciences, 47, 2317-2324. https://doi.org/10.12988/ams.2015.53213

Kleinke, C. L. (2007). What Does It Mean to Cope. In A. Monat, R. S. Lazarus, \& G. M. Reevy (Eds.), The Praeger Handbook on Stress and Coping (pp. 289-308). USA: Praeger Publishing.

Ko, M. H., \& Cho, B. H. (2006). Relationship of Internet Addiction and Stress Coping Behaviorsamong the 5th. 6th Graders in Primary School. J Korean Soc Sch Health, 19(1), 45-54.

Korkmaz, H. (2017). 16-24 Yaş Arası Öğrencilerin Yoğun ve Bağımlı İnternet Kullanımı ile Sosyal Görünüş Kaygıları Arasındaki İlişki. Yüksek Lisans Tezi, Üsküdar Üniversitesi, Sosyal Bilimler Enstitüsü, İstanbul.

Koronczai, B., Kökönyei, G., Urbán, R., Kun, B., Pápay, O., Nagygyörgy, K., ... \& Demetrovics, Z. (2013). The mediating effect of self-esteem, depression and anxiety between satisfaction with body appearance and problematic internet use. The American journal of drug and alcohol abuse, 39(4), 259-265. https://doi.org/10.3109/00952990.2013.803111

Kutlu, M., Savcı, M., Demir, Y., \& Aysan, F. (2016). Young İnternet Bağımlılı̆̆ı Testi Kısa Formunun Türkçe Uyarlaması: Üniversite Öğrencileri ve Ergenlerde Geçerlilik ve Güvenilirlik Çalışması. Anadolu Psikiyatri Dergisi, 17(1), 69-76. https://doi.org/10.5455/apd.190501

Lazarus, R. S., \& Folkman, S. (1984). Stress: Appraisal and Coping. New York: Springer Publishing Company.

Leary, M. R., \& Kowalski, R. M. (1995). Social Anxiety. Guilford, New York.

Lee, B. W., \& Stapinski, L. A. (2012). Seeking Safety on the Internet: Relationship Between Social Anxiety and Problematic Internet Use. Journal of Anxiety Disorders, 26(1), 197-205. https://doi.org/10.1016/j.janxdis.2011.11.001

Levinson, C. A., Rodebaugh, T. L., White, E. K., Menatti, A. R., Weeks, J. W., Iacovino, J. M., \& Warren, C. S. (2013). Social appearance anxiety, perfectionism, and fear of negative evaluation. Distinct or shared risk factors for social anxiety and eating disorders?. Appetite, 67(2013), 125-133. https://doi.org/10.1016/j.appet.2013.04.002

Li, D., Zhang, W., Li, X., Zhou, Y., Zhao, L., \& Wang, Y. (2016). Stressful life events and adolescent Internet addiction: The mediating role of psychological needs satisfaction and the moderating role of coping style. Computers in Human Behavior, 63, 408-415. https://doi.org/10.1016/j.chb.2016.05.070

Li, M. H. (2008). Helping college students cope: Identifying predictors of active coping in different stressful situations. Journal of Psychiatry, Psychology and Mental Health, 2(1), 1-15.

Li, Y., Wang, Y., Ren, Z., Gao, M., Liu, Q., Qiu, C., \& Zhang, W. (2020). The influence of environmental pressure on Internet Use Disorder in adolescents: The potential mediating role of cognitive function. Addictive behaviors, 101, 105976. https://doi.org/10.1016/j.chb.2018.09.001

Maren, S., \& Holmes, A. (2016). Stress and fear extinction. Neuropsychopharmacology, 41(1), 58-79. https://doi.org/10.1038/npp.2015.180

Mihajlov, M., \& Vejmelka, L. (2017). Internet addiction: a review of the first twenty years. Psychiatria Danubina, 29(3), 260-272. https://doi.org/10.24869/psyd.2017.260

Monro, F., \& Huon, G. (2005). Media-portrayed idealized images, body shame, and appearance anxiety. International Journal of Eating Disorders, 38(1), 85-90. https://doi.org/10.1002/eat.20153 
Mülazımoğlu Ballı, Ö., Erturan İlker, G., \& Arslan, Y. (2014). Achievement Goals in Turkish High School PE Setting: The Predicting Role of Social Physique Anxiety. International Journal of Educational Research, 67, 30-39. https://doi.org/10.1016/j.ijer.2014.04.004

Naish, K. R., Laliberte, M., MacKillop, J., \& Balodis, I. M. (2019). Systematic review of the effects of acute stress in binge eating disorder. European Journal of Neuroscience, 50(3), 2415-2429. https://doi.org/10.1111/ejn.14110

Netzley, P. D. (2014). Is Online Addiction a Serious Problem? ReferencePoint Press.

Pawlikowski, M., Altstötter-Gleich, C., \& Brand, M. (2013). Validation and psychometric properties of a short version of Young's Internet Addiction Test. Computers in Human Behavior, 29(3), 1212-1223. https://doi.org/10.1016/j.chb.2012.10.014

Reilly, A., \& Rudd, N. A. (2007). Stress and dress: Investigating the relationship between social anxiety and appearance management among gay and straight men. Journal of Homosexuality, 52(3-4), 151-166. https://doi.org/10.1300/J082v52n03_07

Rodgers, R. F. (2016). The relationship between body image concerns, eating disorders and internet use, part II: An integrated theoretical model. Adolescent Research Review, 1(2), 121-137. https://doi.org/10.1007/s40894-015-0017-5

Rodgers, R. F., Melioli, T., Laconi, S., Bui, E., \& Chabrol, H. (2013). Internet addiction symptoms, disordered eating, and body image avoidance. Cyberpsychology, Behavior, and Social Networking, 16(1), 56-60. https://doi.org/10.1089/cyber.2012.1570

Ryan, C. L., \& Lewis, J. M. (2017). Computer and internet use in the United States: 2015. US Department of Commerce, Economics and Statistics Administration, US Census Bureau.

Şahin, C., \& Korkmaz, Ö. (2011). İnternet Bağımlılı̆̆ Ölçeğinin Türkçeye Uyarlanması. Selçuk Üniversitesi Ahmet Keleşoğlu Eğitim Fakültesi Dergisi, 32, 101-115.

Şahin, N. H. (1994). Stresle Başa Çıkma. Türk Psikologlar Derneği Yayını, Ankara: Özyurt Matbaası.

Şahin, N. H., \& Durak, A. (1995). Stresle Başa Çıkma Tarzları Ölçeği: Üniversite Öğrencileri İçin Uyarlanması. Psikoloji Dergisi, 10(34), 56-73.

Silva, M. A., Taquette, S. R., \& Coutinho, S. F. (2014). Senses of Body Image in Adolescents in Elementary School. Revista De Saude Publica, 48(3), 438-444. https://doi.org/10.1590/S0034-8910.2014048005083

Soponaru, C., Bojian, A., \& Iorga, M. (2016). Gender differences regarding body image, stress and coping strategies in adolescence. Arch Med Sci Civil Dis, 1, 36-42. https://doi.org/10.5114/amscd.2016.59897

Thoits, P. A. (1995). Stress, Coping and Social Support Processes: Where are We? What Next?. Journal of Health and Social Behavior, 53-79. https://doi.org/10.2307/2626957

Tras, Z., Öztemel, K., \& Baltaci, U. B. (2019). Role of Problematic Internet Use, Sense of Belonging and Social Appearance Anxiety in Facebook Use Intensity of University Students. International Education Studies, 12(8), 1-10. https://doi.org/10.5539/ies.v12n8p1

Weinstein, A., Dorani, D., Elhadif, R., Bukovza, Y., \& Yarmulnik, A. (2015). Internet Addiction is Associated with Social Anxiety in Young Adults. Annals of Clinical Psychiatry, 27(1).

Yılmaz, N. (2016). Ergenlerde Problemli Internet Kullanımının Yordayıcıları Olarak Stresle Başa Çıkma ve Kişilik Özellikleri. Yüksek Lisans Tezi, Ankara Üniversitesi, Eğitim Bilimleri Enstitüsü, Ankara.

Young, K. S. (1998). Caught in The Net: How to Recognize the Signs of Internet Addiction-and a Winning Strategy for Recovery. John Wiley \& Sons.

Young, K. S. (2004). Internet Addiction: A New Clinical Phenomenon and Its Consequences. American Behavioral Scientist, 48(4), 402-415. https://doi.org/10.1177/0002764204270278

Young, K. S. (2007). Cognitive Behavior Therapy with Internet Addicts: Treatment Outcomes and Implications. Cyber Psychology \& Behavior, 10(5), 671-679. https://doi.org/10.1089/cpb.2007.9971

Young, K. S. (2017). The Evolution of Internet Addiction Disorder. Internet Addiction (pp. 3-18). Springer. https://doi.org/10.1007/978-3-319-46276-9_1

Zhou, Y., Li, D., Li, X., Wang, Y., \& Zhao, L. (2017). Big five personality and adolescent Internet addiction: The mediating role of coping style. Addictive behaviors, 64, 42-48. 
https://doi.org/10.1016/j.addbeh.2016.08.009

\section{Copyrights}

Copyright for this article is retained by the author(s), with first publication rights granted to the journal.

This is an open-access article distributed under the terms and conditions of the Creative Commons Attribution license (http://creativecommons.org/licenses/by/4.0/). 